\title{
Socioeconomic Status and Perceived Health-related Quality of Life in Chile
}

\author{
Isabel Matute MPH, Soledad Burgos PhD, Tania Alfaro MD MPH
}

\begin{abstract}
INTRODUCTION Changes in the conceptualization of health and illness have led to development of theory and methods to study healthrelated quality of life. One instrument used frequently to measure this concept is the SF-12 survey, included in the Second National Health Survey carried out in Chile between 2009 and 2010.
\end{abstract}

OBJECTIVE Estimate the association between socioeconomic status stratifiers and health-related quality of life in the adult population residing in Chile.

METHODS We conducted a cross-sectional study of a subsample of the National Health Survey, in the population aged $\geq 25$ years. Healthrelated quality of life was operationalized from two SF-12 composite scales: physical health-related quality of life and mental health-related quality of life. Both were categorized as good or poor relative to their median scores. Socioeconomic status stratifiers were education, employment status and monthly per capita household income. Multiple logistic regression models were generated for physical health-related quality of life and mental health-related quality of life, according to socioeconomic status stratifiers adjusted for several covariates.

\section{INTRODUCTION}

In recent decades, analysis of the health-illness process has been challenged to find indicators that complement traditional indicators centered on mortality and morbidity, and that incorporate selfassessment of health and well-being. This has led to development of theory and methods to study health-related quality of life (HRQOL), the sense of well-being derived from the subjective assessment of one's own health status.[1,2] Introduction of this concept and the proliferation of instruments for measuring it have become very important due to its association with indicators of mortality, hospitalization and health service utilization.[3]

A person's subjective appreciation of their own health depends on their economic, cultural and social context.[2,4,5] One analytical approach to context-related interindividual differences focuses on the influence of social determinants of health, and suggests that people experience distinct exposures and vulnerabilities according to their socioeconomic status (SES), which condition their opportunities as well as their health status.[6,7] Research on the association between SES stratifiers and HRQOL is of particular interest, as are the mechanisms by which SES influences subjective health assessment. Although the social determinant approach has been broadly applied to studying population health status, it lacks quantitative models for explaining constructs such as perceived health, in which attitudes and socialization processes (the moods, emotions, memories and beliefs that health as the object of assessment arouses in the subject) also play a role.[8]

Several studies explain the relationship of health status to conditioning factors such as education, [9,10] employment[9-13] and income,[12,14] but there are few studies of the association between SES indicators and HRQOL. Some show poorer well-
RESULTS The sample comprised 4473 respondents, $51.6 \%$ women, median age 47.8 years. The probability of poor quality of life was higher in persons with only primary school education, those not in the workforce and those whose monthly income was below 100,815 Chilean pesos (US\$140); the effect was stronger for physical healthrelated quality of life (OR $2.8,95 \% \mathrm{Cl} 1.8-4.2$; OR $1.7,95 \% \mathrm{Cl} 1.2-2.3$ and $\mathrm{OR} 2.2,95 \% \mathrm{Cl} 1.3-3.8$, respectively) than for mental healthrelated quality of life (OR 1.4, 95\% Cl 1.1-1.8; OR 1.6, 95\% CI 1.2-2.2 and $\mathrm{OR} 1.9,95 \% \mathrm{Cl} 1.1-3.0$, respectively).

CONCLUSIONS The probability of poor health-related quality of life is higher in the worst socioeconomic status strata, and the effect is most pronounced in the most vulnerable groups. The direct effect of social stratifiers on living conditions and access to services-both strong influences on subjective health-would explain this finding and highlight the need to adopt equity-oriented strategies aimed at addressing the impact of socioeconomic status on health-related quality of life.

KEYWORDS Health-related quality of life, socioeconomic factors, social class, health status disparities, inequalities, health equity, health disparities, social determinants of health, Chile

being in persons with lower levels of education, $[4,15]$ and a similar association with HRQOL.[16-18] Other studies show an association between employment status and well-being,[15] as well as a worse perception of health in retired or unemployed persons.[16,19] Some studies also examine the relationship between income and well-being[4,9,15] and HRQOL.[5,16-19]

In Chile, several studies have applied one of the generic surveys most frequently utilized to measure HRQOL, the SF-12 Short Form Survey (abbreviated from a 36-item survey).[20] This instrument was used for the first time in Chile in the Second Health and Quality of Life Survey (2006), which found significant differences in perceived health between the highest and lowest socioeconomic groups.[21] The SF-12 was used again in the 2010 Second National Health Survey (ENS), but its results have not been analyzed for the Chilean population nor in relation to the importance of socioeconomic determinants.[22]

This study analyzed ENS data to estimate the association between SES stratifiers and HRQOL in the population aged $\geq 25$ years residing in Chile, under the hypothesis that HRQOL is worse for SES indicator values that imply greater social vulnerability.

\section{METHODS}

A cross-sectional analytical study using data from the 2009-2010 ENS was carried out by the Ministry of Health and the Universidad Católica de Chile. The ENS sample design was a complex one with multistage probability sampling. The sample of 5293 people aged $\geq 15$ years (base population $13,355,826$ ) was representative nationally, regionally, by urban and rural area of residence, by sex and age. Given the interest in analyzing SES indicators that 
require a certain degree of individual autonomy, this study only considered respondents aged $\geq 25$ years, corresponding to a subsample of 4490 persons (2.3\% error). Some 17 people who did not respond to the SF-12 survey were excluded, for a final sample of 4473 (base population 10,419,141, $84.5 \%$ of the 2010 ENS sample).

The ENS included morbidity and health questionnaires, anthropometric and physiological measurements, and blood and urine samples. Field research was conducted between October 16, 2009 and September 6, 2010. Data were entered directly into personal digital assistants. Data analysis was done at the Universidad Católica de Chile. The ENS protocol was approved by the Research Ethics Committee of the Universidad Católica de Chile Medical School. Information was gathered following signed informed consent, and assurance of confidentiality of sample collection and delivery of results.[23]

HRQOL was measured with the SF-12 v. 2 survey, which consists of 12 questions grouped in eight health domains: general health, physical functioning, bodily pain, vitality, mental health, social functioning, and role functioning (physical and emotional); and two composite scales, physical and mental HRQOL (all scores weighted and summed; value range 0-100). $[20,24]$ Independent variables assessed were SES stratifiers: educational level (years of education, and grouped as primary or less, secondary, and higher), employment status in the last year (employed, unemployed, and not in the workforce-such as homemakers, students, pensioners or those unable to work due to disability) and monthly per capita household income (total household income / number of members aged $\geq 20$ years) in groups corresponding to categories of the 2009 National Socioeconomic Characterization Survey:[25] <100,815 Chilean pesos (<US\$140), 100,815 to 286,399 Chilean pesos (US $\$ 140$ to US\$398) and $>286,399$ Chilean pesos (>US\$398). The following covariates were controlled: sex, age, area of residence (urban or rural), type of health insurance (public insurance through the National Health Fund, FONASA; private insurance through health insurance institutions, ISAPRE; other), presence of chronic conditions (high blood pressure, diabetes or excess weight), and symptoms of depression.

Complex sampling techniques were applied for all estimations using the complex samples module of SPSS v. 19. Five steps were carried out: 1) calculation of SF-12 scores using procedures described by the instrument's developers;[24] 2) analysis of SF12's metric properties (Cronbach alpha for internal consistency and principal component factor analysis for content validity); 3) descriptive analysis of SF-12 (measures of central tendency and dispersion), and score categorization based on values in two levels: good HRQOL (values above the median) and poor HRQOL (values below the median); 4) bivariate analysis of the distribution of physical and mental HRQOL (categorized variables) according to predictors of interest and covariate adjustment, using logistic regression to compare adjusted ORs with 95\% confidence intervals, using $p<0.05$ as the significance threshold; and 5) multiple logistic regression models generated for each HRQOL composite scale separately by SES stratifier and controlled for covariates that were statistically significant in bivariate analysis. Adjusted ORs were used as estimates of association between SES stratifiers and poor HRQOL.

\section{RESULTS}

Study population characteristics Women comprised $51.6 \%$ of the sample; median age was 47.8 years, and $48.4 \%$ were aged $25-44$ years. The majority resided in urban areas (86.6\%), and $77.9 \%$ were covered by FONASA. Average education completed was 10.4 years, and $43.9 \%$ had finished secondary school; more than half the population was employed (58.1\%); average monthly per capita household income was CL\$110,283 (US\$153), and 65.5\% lived in households with monthly per capita income <CL $\$ 100,815$ (US\$140). With respect to health, $49.6 \%$ had one of the chronic conditions included in the survey; $29.4 \%$ had two or more conditions; and $18.1 \%$ reported symptoms of depression (Table 1 ).

HRQOL and SF-12 psychometric properties Median physical HRQOL was 52.5 (interquartile range 12.7), and median mental HRQOL was 51.5 (interquartile range 13.4) (Table 2). Cronbach

Table 1: Sample characteristics, population aged $\geq 25$ years, Chile (ENS 2010, $n=4473^{\text {a) }}$

\begin{tabular}{|c|c|}
\hline Characteristic & $\begin{array}{l}\text { Estimate } \\
\%(95 \% \mathrm{Cl})\end{array}$ \\
\hline \multicolumn{2}{|l|}{ Sex } \\
\hline Male & $48.4(45.8-51.0)$ \\
\hline Female & $51.6(49.0-54.2)$ \\
\hline Median age (years) & $47.8(47.1-48.6)$ \\
\hline \multicolumn{2}{|l|}{ Age group } \\
\hline $25-44$ years & $48.4(45.7-51.1)$ \\
\hline $45-64$ years & $36.5(33.8-39.3)$ \\
\hline$\geq 65$ years & $15.1(13.3-17.1)$ \\
\hline \multicolumn{2}{|l|}{ Area of residence $\left(n=4472^{b}\right)$} \\
\hline Urban & $86.6(84.7-88.4)$ \\
\hline Rural & $13.4(11.6-15.3)$ \\
\hline \multicolumn{2}{|c|}{ Type of health insurance $\left(n=4433^{b}\right)$} \\
\hline Public insurance (FONASA) & $77.9(74.7-80.7)$ \\
\hline Private insurance (ISAPRE) & $12.5(10.2-15.3)$ \\
\hline Other ${ }^{b}$ & $9.6(8.1-11.4)$ \\
\hline \multicolumn{2}{|l|}{ Educational level $\left(n=4467^{\circ}\right)$} \\
\hline Higher & $22.3(19.2-25.8)$ \\
\hline Secondary & $43.9(41.1-46.8)$ \\
\hline Primary or less & $33.8(31.1-36.5)$ \\
\hline \multicolumn{2}{|c|}{ Employment status $\left(n=4455^{\circ}\right)$} \\
\hline Employed & $58.1(55.3-0.7)$ \\
\hline Unemployed & $3.0(2.3-4.0)$ \\
\hline Not in the workforce & $38.9(36.3-41.6)$ \\
\hline \multicolumn{2}{|c|}{ Monthly per capita household income $\left(n=4303^{\circ}\right)$} \\
\hline$>C L \$ 286,399$ & $6.4(5.3-7.8)$ \\
\hline CL\$100,815 to CL\$286,399 & $28.1(25.7-30.7)$ \\
\hline$<C L \$ 100,815$ & $65.5(62.6-68.2)$ \\
\hline \multicolumn{2}{|c|}{$\begin{array}{l}\text { Chronic condition (high blood pressure, diabetes } \\
\text { or excess body weight) }\left(n=3872^{c}\right)\end{array}$} \\
\hline 0 & $20.9(18.5-23.6)$ \\
\hline 1 & $49.6(46.9-52.4)$ \\
\hline $2-3$ & $29.4(27.0-32.0)$ \\
\hline \multicolumn{2}{|c|}{ Symptoms of depression $\left(n=3931^{b}\right)$} \\
\hline No & $81.9(79.5-84.1)$ \\
\hline Yes & $18.1(15.9-20.5)$ \\
\hline
\end{tabular}

abase population $10,419,141$

bincludes armed forces, no health insurance or other insurance

cvariation in sample size due to nonresponse to some variables

CL: Chilean pesos $\quad$ ENS: National Health Survey

FONASA: National Health Fund ISAPRE: health insurance institution 
Table 2: SF-12 results, population aged $\geq 25$ years, Chile (ENS 2010, $n=4473^{a}$ )

\begin{tabular}{|l|r|r|r|r|r|r|}
\hline Composite or scale score $^{\text {b }}$ & Median & Minimum & Maximum & P25 & P75 & IQR \\
\hline Physical HRQOL composite scale & 52.5 & 13.8 & 70.2 & 44.4 & 57.0 & 12.7 \\
\hline Mental HRQOL composite scale & 51.5 & 13.6 & 75.1 & 43.9 & 57.3 & 13.4 \\
\hline Physical functioning & 56.9 & 24.9 & 56.9 & 40.9 & 56.9 & 16.0 \\
\hline Role functioning, physical & 54.4 & 24.3 & 58.7 & 41.5 & 58.7 & 17.2 \\
\hline Bodily pain & 51.7 & 28.6 & 59.4 & 44.0 & 59.4 & 15.4 \\
\hline General health & 55.8 & 31.9 & 71.5 & 41.8 & 55.7 & 13.9 \\
\hline Vitality & 53.7 & 26.3 & 62.8 & 44.6 & 53.7 & 9.1 \\
\hline Social functioning & 50.0 & 25.2 & 58.3 & 41.8 & 58.3 & 16.5 \\
\hline Role functioning, emotional & 53.7 & 20.0 & 58.5 & 44.1 & 58.5 & 14.4 \\
\hline Mental health & 48.6 & 21.9 & 64.7 & 43.3 & 59.3 & 16.0 \\
\hline
\end{tabular}

abase population $10,419,141$

ball scores weighted and summed; value range 0-100; standardized with mean 50, SD 10[24]

ENS: National Health Survey HRQOL: health-related quality of life

P25: 25th percentile P75: 75 th percentile

IQR: interquartile range
Table 5 displays results of multivariate models generated to analyze SES stratifiers' effects on physical HRQOL and adjusted ORs for control variables. Risk of poor HRQOL was greater in persons with primary education or less compared to those with higher education, (OR 2.8, $95 \% \mathrm{Cl} 1.8-4.2$,$) .$

Risk of poor HRQOL was higher for persons not in the workforce than for employed persons (OR 1.7, 95\% Cl 1.2-2.3). Persons with monthly per capita household income <CL\$100,815 also had higher risk of poor HRQOL than those with incomes >CL\$286,399 (OR $2.2,95 \% \mathrm{Cl} 1.3-3.8)$. alpha was 0.84 , and principal component factor analysis confirmed the existence of two components: scales of physical function, physical role, bodily pain and general health associated with physical HRQOL; and scales of vitality, social function, emotional role and mental health linked to mental HRQOL.

Physical HRQOL The proportion of people with poor physical HRQOL increased as educational level decreased (Table 3). With higher education as the reference category, the ORs for poor physical HRQOL associated with secondary and primary education or less were 1.8 and 4.6, respectively. Poor HRQOL was also more frequent among people who were not in the workforce and in those whose monthly per capita household income was $<$ CL $\$ 100,815$.

Poor physical HRQOL was more frequent in women, in people aged $\geq 65$ years compared to both younger age groups (25-44 and 45-64 years), in residents of rural areas, in FONASA enrollees (compared to those covered by ISAPREs or other insurance), and in persons with two or more chronic conditions (compared to those with none or one), and in people with symptoms of depression (Table 4).
Mental HRQOL Differences by SES were also observed in mental HRQOL (Table 3), with a greater probability of poor HRQOL in persons with primary education or less, not in the workforce, and with monthly per capita household income <CL\$100,815.

Mental HRQOL exhibited differences by sex (greater probability of poor HRQOL in women), type of health insurance (greater probability of poor HRQOL in FONASA enrollees), and symptoms of depression (greater probability of poor HRQOL in those with symptoms). Differences by age, area of residence and chronic disease were not significant.

When controlled for covariates (Table 5), the effect of the stratifiers on mental HRQOL was more moderate than for physical HRQOL. Persons with primary education or less reported poor HRQOL more frequently than those who completed higher education (OR $1.4,95 \% \mathrm{Cl} 1.1-1.8)$.

Those not in the workforce had poor HRQOL more frequently than employed persons (OR 1.6, 95\% CI 1.2-2.2). Finally, HRQOL was also worse for those in the lowest monthly per capita household

Table 3: Physical and mental HRQOL by SES, population aged $\geq 25$ years, Chile (ENS 2010, $n=4473^{a}$ )

\begin{tabular}{|c|c|c|c|c|c|c|}
\hline \multirow[b]{2}{*}{ Variable } & \multicolumn{3}{|c|}{ Physical HRQOL } & \multicolumn{3}{|c|}{ Mental HRQOL } \\
\hline & $\begin{array}{c}\text { Good } \\
\%(95 \% \mathrm{Cl})\end{array}$ & $\begin{array}{c}\text { Poor } \\
\%(95 \% \mathrm{Cl})\end{array}$ & $\begin{array}{c}\mathrm{OR}^{\mathrm{b}} \\
(95 \% \mathrm{Cl})\end{array}$ & $\begin{array}{c}\text { Good } \\
\%(95 \% \text { Cl) }\end{array}$ & $\begin{array}{c}\text { Poor } \\
\%(95 \% \mathrm{Cl})\end{array}$ & $\begin{array}{c}\mathrm{OR}^{\mathrm{b}} \\
(95 \% \mathrm{Cl})\end{array}$ \\
\hline \multicolumn{7}{|l|}{ Educational level $\left(n=4467^{\circ}\right)$} \\
\hline Higher & $68.4(62.0-74.2)$ & $31.6(25.8-38.0)$ & Ref & $56.0(50.8-61.1)$ & $44.0(38.9-49.2)$ & Ref \\
\hline Secondary & $54.5(50.4-58.5)$ & $45.5(41.5-49.6)$ & $1.8(1.3-2.5)$ & $50.8(47.2-54.4)$ & $49.2(45.6-52.8)$ & $1.2(0.9-1.6)$ \\
\hline Primary or less & $32.1(28.6-35.7)$ & $67.9(64.3-71.4)$ & $4.6(3.3-6.4)$ & $44.9(41.2-48.6)$ & $55.1(51.4-58.8)$ & $1.6(1.2-2.0)$ \\
\hline \multicolumn{7}{|c|}{ Employment status $\left(n=4455^{\circ}\right)$} \\
\hline Employed & $60.9(57.2-64.4)$ & $39.1(35.6-42.8)$ & Ref & $56.3(53.1-59.5)$ & $43.7(40.5-46.9)$ & Ref \\
\hline Unemployed & $43.2(31.0-56.3)$ & $56.8(43.7-69.0)$ & $2.0(1.2-3.5)$ & $44.2(31.5-57.7)$ & $55.8(42.3-68.5)$ & $1.6(0.9-2.9)$ \\
\hline Not in workforce & $33.9(30.4-37.6)$ & $66.1(62.4-69.6)$ & $3.0(2.4-3.8)$ & $40.5(37.2-43.9)$ & $59.5(56.1-62.8)$ & $1.9(1.6-2.3)$ \\
\hline \multicolumn{7}{|c|}{ Monthly per capita household income $\left(n=4303^{\circ}\right)$} \\
\hline$>C L \$ 286,399$ & $69.6(61.0-77.1)$ & $30.4(22.9-39.0)$ & Ref & $61.2(51.2-70.3)$ & $38.8(29.7-48.8)$ & Ref \\
\hline CL\$100,815 to CL $\$ 286,399$ & $55.9(50.9-60.8)$ & $44.1(39.2-49.1)$ & $1.8(1.2-2.8)$ & $58.2(52.8-63.3)$ & $41.8(36.7-47.2)$ & $1.1(0.7-1.8)$ \\
\hline$<\mathrm{CL} \$ 100,815$ & $42.9(39.5-46.2)$ & $57.1(53.8-60.5)$ & $3.0(2.0-4.5)$ & $44.9(41.7-48.1)$ & $55.1(51.9-58.3)$ & $1.9(1.2-3.0)$ \\
\hline
\end{tabular}


Table 4: Physical and mental HRQOL by covariates, population aged $\geq 25$ years, Chile (ENS 2010, $n=4473^{\mathrm{a}}$ )

\begin{tabular}{|c|c|c|c|c|c|c|}
\hline \multirow[b]{2}{*}{ Variables } & \multicolumn{3}{|c|}{ Physical HRQOL } & \multicolumn{3}{|c|}{ Mental HRQOL } \\
\hline & $\begin{array}{c}\text { Good } \\
\%(95 \% \mathrm{Cl})\end{array}$ & $\begin{array}{c}\text { Poor } \\
\%(95 \% \mathrm{Cl})\end{array}$ & $\mathbf{O R}^{\mathrm{b}}$ & $\begin{array}{c}\text { Good } \\
\%(95 \% \mathrm{CI})\end{array}$ & $\begin{array}{c}\text { Poor } \\
\%(95 \% \mathrm{Cl})\end{array}$ & $\begin{array}{c}\mathrm{OR}^{\mathrm{b}} \\
(95 \% \mathrm{Cl})\end{array}$ \\
\hline \multicolumn{7}{|l|}{ Sex } \\
\hline Male & $57.7(53.7-61.5)$ & $42.3(38.5-46.3)$ & Ref & $58.7(54.6-62.6)$ & $41.3(37.4-45.4)$ & Ref \\
\hline Female & $42.8(39.8-45.9)$ & $57.2(54.1-60.2)$ & $1.8(1.5-2.2)$ & $41.8(39.1-44.6)$ & $58.2(55.4-60.9)$ & $2.0(1.6-2.4)$ \\
\hline \multicolumn{7}{|l|}{ Age group (years) } \\
\hline $25-44$ & $61.2(57.0-65.3)$ & $38.8(34.7-43.0)$ & Ref & $51.5(48.1-54.9)$ & $48.5(45.1-51.9)$ & Ref \\
\hline $45-64$ & $45.4(41.4-49.5)$ & $54.6(50.5-58.6)$ & $1.9(1.5-2.4)$ & $47.1(43.2-50.9)$ & $52.9(49.1-56.8)$ & $1.2(1.0-1.5)$ \\
\hline$\geq 65$ & $25.2(20.6-30.5)$ & $74.8(69.5-79.4)$ & $4.7(3.4-6.4)$ & $52.2(46.7-57.6)$ & $47.8(42.4-53.3)$ & $1.0(0.8-1.3)$ \\
\hline \multicolumn{7}{|c|}{ Area of residence $\left(n=4472^{c}\right)$} \\
\hline Urban & $52.2(49.2-55.3)$ & $47.8(44.7-50.8)$ & Ref & $50.2(47.7-52.8)$ & $49.8(47.2-52.3)$ & Ref \\
\hline Rural & $35.5(31.3-40.0)$ & $64.5(60.0-68.7)$ & $2.0(1.5-2.5)$ & $48.3(41.4-55.3)$ & $51.7(44.7-58.6)$ & $1.1(0.8-1.5)$ \\
\hline \multicolumn{7}{|c|}{ Type of health insurance $\left(n=4433^{\circ}\right)$} \\
\hline Private (FONASA) & $71.9(64.2-78.5)$ & $28.1(21.5-35.8)$ & Ref & $59.5(51.2-67.2)$ & $40.5(32.8-48.8)$ & Ref \\
\hline Public (ISAPRE) & $45.4(42.8-48.1)$ & $54.6(51.9-57.2)$ & $3.1(2.1-4.5)$ & $48.4(45.9-50.9)$ & $51.6(49.1-54.1)$ & $1.6(1.1-2.2)$ \\
\hline Other ${ }^{d}$ & $59.5(51.2-67.4)$ & $40.5(32.6-48.8)$ & $1.7(1.1-2.8)$ & $53.3(43.7-62.7)$ & $46.7(37.3-56.3)$ & $1.3(0.8-2.2)$ \\
\hline \multicolumn{7}{|c|}{ Chronic condition (high blood pressure, diabetes or excess weight) $\left(n=3872^{\circ}\right.$ ) } \\
\hline 0 & $63.4(57.7-68.7)$ & $36.6(31.3-42.3)$ & Ref & $51.3(45.3-57.3)$ & $48.7(42.7-54.7)$ & Ref \\
\hline 1 & $53.7(49.4-57.9)$ & $46.3(42.1-50.6)$ & $1.5(1.1-2.0)$ & $50.9(47.4-54.4)$ & $49.1(45.6-52.6)$ & $1.0(0.8-1.4)$ \\
\hline $2-3$ & $35.4(31.1-39.9)$ & $64.6(60.1-68.9)$ & $3.2(2.3-4.3)$ & $47.7(43.5-51.9)$ & $52.3(48.1-56.5)$ & $1.2(0.8-1.6)$ \\
\hline \multicolumn{7}{|c|}{ Symptoms of depression $\left(n=3931^{\circ}\right)$} \\
\hline No & $55.0(51.7-58.2)$ & $45.0(41.8-48.3)$ & Ref & $62.5(59.7-65.3)$ & $37.5(34.7-40.3)$ & Ref \\
\hline Yes & $32.4(26.5-38.8)$ & $67.6(61.2-73.5)$ & $2.6(1.9-3.5)$ & $11.8(8.2-16.8)$ & $88.2(83.2-91.8)$ & $12.5(8.1-19.1)$ \\
\hline
\end{tabular}

abase population $10,419,141 \quad$ b crude odds ratio $\quad$ cvariation in sample size due to nonresponse for some variables

dincludes armed forces, no health insurance or other insurance ENS: National Health Survey FONASA: National Health Fund

HRQOL: health-related quality of life ISAPRE: health insurance institution n: sample size Ref: reference group

Table 5: Poor physical and mental HRQOL and socioeconomic variables, population aged 25 years, Chile, (ENS 2010)

\begin{tabular}{|c|c|c|c|c|}
\hline \multirow[b]{2}{*}{ Variable } & \multicolumn{2}{|c|}{ HRQOL physical health } & \multicolumn{2}{|c|}{ HRQOL mental health } \\
\hline & $\begin{array}{l}\text { Crude OR } \\
(95 \% \mathrm{CI})\end{array}$ & $\begin{array}{c}\text { Adjusted OR } \\
(95 \% \mathrm{CI})\end{array}$ & $\begin{array}{l}\text { Crude OR } \\
(95 \% \mathrm{CI})\end{array}$ & $\begin{array}{l}\text { Adjusted OR } \\
\qquad(95 \% \mathrm{CI})\end{array}$ \\
\hline \multicolumn{5}{|l|}{ Educational level } \\
\hline Higher & Ref & Ref & Ref & Ref \\
\hline Secondary & $1.8(1.3-2.5)$ & $1.6^{\mathrm{a}}(1.1-2.1)$ & $1.2(0.9-1.6)$ & $1.2^{b}(0.9-1.6)$ \\
\hline Primary or less & $4.6(3.3-6.4)$ & $2.8^{\mathrm{a}}(1.8-4.2)$ & $1.6(1.2-2.0)$ & $1.4^{\mathrm{b}}(1.1-1.8)$ \\
\hline \multicolumn{5}{|l|}{ Employment status } \\
\hline Employed & Ref & Ref & Ref & Ref \\
\hline Unemployed & $2.0(1.2-3.5)$ & $1.9^{c}(0.9-3.7)$ & $1.6(0.9-2.9)$ & $1.6^{\mathrm{b}}(0.8-3.1)$ \\
\hline Not in workforce & $3.0(2.4-3.8)$ & $1.7^{c}(1.2-2.3)$ & $1.9(1.6-2.3)$ & $1.6^{b}(1.2-2.2)$ \\
\hline \multicolumn{5}{|c|}{ Monthly per capita household income ${ }^{c}$} \\
\hline$>C L \$ 286,399$ & Ref & Ref & Ref & Ref \\
\hline CL $\$ 100,815$ to $C L \$ 286,399$ & $1.8(1.2-2.8)$ & $1.4^{\mathrm{c}}(0.8-2.5)$ & $1.1(0.7-1.8)$ & $1.2^{\mathrm{d}}(0.7-2.1)$ \\
\hline$<C L \$ 100,815$ & $3.0(2.0-4.5)$ & $2.2^{\mathrm{c}}(1.3-3.8)$ & $1.9(1.2-3.0)$ & $1.9^{d}(1.1-3.0)$ \\
\hline
\end{tabular}

aadjusted for sex, age group, health insurance system, chronic conditions, symptoms of depression badjusted for sex, age group, chronic conditions, symptoms of depression

cadjusted for sex, age group, residence, health insurance system, chronic conditions, symptoms of depression dadjusted for sex, age group, chronic conditions, symptoms of depression

ENS: National Health Survey HRQOL: health-related quality of life

Ref: reference group poor $\mathrm{HRQOL}$ had primary education or less, were not participating in the workforce, or had a monthly household per capita income $<C L \$ 100,815$ could be due to a direct effect of their living conditions and access to health services, which are themselves determinants of subjective health. Persons with low SES had more health problems and fewer resources to address them, which, as Delpierre suggests,[17] influences perceived HRQOL.

Several studies in the international literature agree with our assessment of SES's effects on perceived health.[5,16-19,26] In general, better HRQOL is found in higher-income groups,[5,16-19], just as subjective health assessment is worse among unemployed or retired persons, $[16,19]$ which could be due to a higher proportion of women aged $\geq 65$ years and people with chronic health conditions in that group.

In Chile, studies of perceived health have also identified differences associated with SES and worse perception in the quintiles with the least income category $(<C L \$ 100,814)$ than for those in the highest category (OR 1.9, 95\% Cl 1.1-3.0).

\section{DISCUSSION}

Our analysis revealed differences in both physical and mental HRQOL. The most vulnerable groups according to SES stratifiers always perceived the worst HRQOL, unlike groups in intermediate strata. The fact that those with a greater probability of resources,[27-29] as well as a positive association between perceived health and being employed and socioeconomic status.[21]

Even though international evidence is not absolutely consistent regarding the relationship between $\mathrm{HRQOL}$ and sex, $[4,5,16]$ our results are consistent with those of earlier Chilean studies that reported poorer HRQOL in women,[21,27,28,30-32] which may be linked both to their position in the social structure as 
well as to their living conditions, characterized by the worst indicators for education, income, poverty and employment status. $[25,27,28,33]$

In terms of physical health, poor HRQOL was more frequent among people aged $\geq 65$ years. There was no significant difference in relation to mental health in this age group. This coincides with previous studies [32,34], so it can be inferred that deteriorating physical conditions and functions associated with increasing chronic disease become more noticeable with advancing age. Perception of mental health may be linked to satisfaction with life, beyond health as such. There is evidence of a U-shaped association with age that describes high subjective well-being in young people, lower in adults, and high again in older adults, $[15,33,35]$ interpreted as owing to a change in older peoples' expectations that translates as greater satisfaction with their time of life.

Regarding the health insurance system, as with prior analyses,[32] this study showed worse HRQOL in public health enrollees, among whom there is a high proportion of older adults and people with comorbidities compared to private insurance enrollees. $[25,27,28,33,36]$

The results for chronic conditions coincide with a 2006 study that found illness or disability to be the factor with greatest influence on perceived physical health.[21]

Although differences were observed by SES in both physical and mental HRQOL, they were most marked in the physical dimension. This could be due to a more direct effect of SES on people's physical health, given worse living and working conditions among the most vulnerable, and to barriers to access to health care and other goods and services that such groups must overcome. The stratifier with greatest influence on physical HRQOL was educational level, which affects health through various mechanisms, as an indicator of the intellectual and material resources of the family of origin, $[9,10]$ and as a determinant of life styles and responsiveness to promotion and prevention messages, as well as of the capacity to interact with health services.[9]

The greater homogeneity in perceived mental HRQOL could be due to other mechanisms that act as intermediaries between stratifiers and HRQOL, such as attitudinal components, social cohesion and social support networks. However, these variables were not included in the 2010 ENS, ruling out analysis of how a person's feelings, emotions, memories and beliefs might affect perceived HRQOL.[8]

Given the cross-sectional nature of the study, we could not establish temporal precedence between SES stratifiers and $\mathrm{HRQOL}$, so it is possible that associations observed were due to an influence by HRQOL on SES, rather than the converse.

Nevertheless, the study is based on the application of an instrument that is widely used internationally, using secondary data and an appropriate methodology for analyzing complex population samples to estimate the population's HRQOL and demonstrate its association with SES stratifiers. This information is of interest from a public health perspective, because perceived health can be a marker of health inequities, due to its association with resources, hospitalizations and mortality.[3,17]

For that reason, and given the limited development of HRQOL analysis in Chile, we recommend further study of the subjective perception of health and its association with living conditions. SES indicators should be optimized and attitudinal aspects explored through qualitative methodologies.

\section{CONCLUSIONS}

SES is associated with perceived HRQOL, with worst HRQOL reported by the most vulnerable socioeconomically. Women, older adults, residents of rural areas, public health enrollees and people with chronic conditions or symptoms of depression have a greater probability of perceiving poor HRQOL. The effect is more pronounced for physical than for mental HRQOL. $\$$ /

\section{REFERENCES}

1. Urzúa M. Calidad de vida relacionada con la salud: Elementos conceptuales. Rev Méd Chile [Internet]. 2010 Mar [cited 2015 Nov 1];138(3):358-65. Available from: http://www .scielo.cl/pdf/rmc/v138n3/art17.pdf. Spanish.

2. Schwarztmann L. Calidad de vida relacionada con la salud: aspectos conceptuales. Cienc Enferm [Internet]. 2003 Dec [cited 2015 Feb10];9(2):9-21. Available from: http://www .scielo.cl/scielo.php?script=sci_abstract\&pid= S0717-95532003000200002\&lng=es\&nrm=iso\&t Ing=es. Spanish.

3. Alonso J. La medida de la calidad de vida relacionada con la salud en la investigación y la práctica clínica. Gac Sanit. 2000;14(2):163-7. Spanish.

4. Zegers Prado B, Rojas-Barahona C, Förster Marín C. Validez y confiabilidad del Índice de Satisfacción Vital (LSI-A) de Neugarten, Havighurst \& Tobin en una Muestra de Adultos y Adultos Mayores en Chile. Ter Psicol. 2009;27(1):15-26. Spanish.

5. Alazraqui M, Diez Roux A, Fleischer N, Spinell $\mathrm{H}$. Salud auto-referida y desigualdades sociales, ciudad de Buenos Aires, Argentina 2005. Cad Saúde Pública. 2009 Sep;25(9):1990-2000. Spanish.

6. Vega J, Solar O, Irwin A. Equidad y determinantes sociales de la salud: conceptos bási- cos, mecanismos de producción y alternativas para la acción. In: Iniciativa Chilena de Equidad en Salud, editor. Determinantes sociales de la salud en Chile: en la perspectiva de la equidad. Santiago de Chile: ICES; 2005. 86 p. Spanish.

7. Borrell C, Artazcoz L. Las políticas para disminuir las desigualdades en salud. Gac Sanit [Internet]. 2008 Sep-Oct [cited 2016 Jan 6];22(5):465-73. Available from: http://scielo .isciii.es/scielo.php?script=sci_arttext\&pid =S0213-91112008000500012. Spanish.

8. Morales J, Huici C. Psicología Social. Madrid: McGraw-Hill; 1999. Spanish.

9. Shavers VL. Measurement of socioeconomic status in health disparities research. J Natl Med Assoc [Internet]. 2007 Sep [cited 2015 Dec 3];99(9):101323. Available from: http://www.pubmedcentral.nih .gov/articlerender.fcgi?artid=2575866\&tool=pmcen tre $z$ \& rendertype=abstract

10. Braveman P, Cubbin C, Egerter S, Chideya S, Marchi KS, Metzler M, et al. Socioeconomic status in health research: one size does not fit all. JAMA [Internet]. 2005 Dec 14 [cited 2015 Nov 16];294(22):2879-88. Available from: https://jama network.com/journals/jama/fullarticle/10.1001/ jama.294.22.2879
11. World Health Organization [Internet]. Geneva: World Health Organization; c2017. Programas y Proyectos. Determinantes Sociales de la Salud. Comisión sobre Determinantes Sociales de la Salud. Subsanar las desigualdades en una generación. Resumen Analítico del Informe Final; 2009 [cited $2015 \mathrm{Dec} 3$ ]; [4.73Mb]. Available from: http://whqlibdoc.who.int/hq/2008/WHO_IER CSDH 08.1 spa.pdf?ua=1. Spanish

12. Galobardes $\bar{B}$, Shaw M, Lawlor DA, Lynch JW, Davey Smith G. Indicators of socioeconomic position (part 1). J Epidemiol Community Health [Internet]. 2006 Jan [cited 2014 Jul 15];60(1):7-12. Available from: http://jech.bmj .com/content/60/1/7=abstract

13. Hoven H, Siegrist J. Work characteristics, socioeconomic position and health: a systematic review of mediation and moderation effects in prospective studies. Occup Environ Med [Internet]. 2013 Sep [cited 2015 Dec 18];70(9):663-9. Available from: http://www.pubmedcentral.nih .gov/articlerender.fcgi ?artid=3756612\&tool=pmc entre $z$ \& rendertype $=$ abstract

14. Galobardes B, Lynch J, Smith GD. Measuring socioeconomic position in health research. $\mathrm{Br}$ Med Bull [Internet]. 2007 Feb 6 [cited 2015 Aug 24];81-82:21-37. Available from: https://acade 
mic.oup.com/bmb/article-lookup/doi/10.1093/ bmb/ldm001

15. van Hoorn A. A short Introduction to subjective wellbeing: Its measurement, correlates and Policy uses. Conference paper for the Second OECD World Forum on Statistics, Kowledge and Policy: Measuring and Foresting the Progress of Societies. Session on Measuring Happiness and Making Policy; 2007 Jun 27-30; Istambul, Turkey; 2007.

16. Kind P, Dolan P, Gudex C, Williams A. Variations in population health status: results from a United Kingdom national questionnaire survey. BMJ. 1998 Mar 7;316(7133):736-41.

17. Delpierre $C$, Kelly-Irving $M$, Munch-Petersen $M$, Lauwers-Cances V, Datta GD, Lepage B, et al. $\mathrm{SRH}$ and HrQOL: does social position impact differently on their link with health status? BMC Public Health [Internet]. 2012 Jan 10 [cited 2016 Jan 5];12:19. Available from: http://www .pubmedcentral.nih.gov/articlerender.fcgi?artid= 3287252\&tool=pmcentre $z \&$ rendertype=abstract

18. Robert S, Cherepanov D, Palta M, Cross Dunham N, Feeny D, Fryback DG. Socioeconomic status and age variations in health-related quality of life: results from the national health measurement study. J Gerontol B Psychol Sci Soc Sci [Internet]. 2009 May [cited 2016 Jan 5];64B(3):378-89. Available from: http://www .pubmedcentral.nih.gov/articlerender.fcgi?artid= 2670253\&tool=pmcentre $z \&$ rendertype $=$ abstract

19. Sun $S$, Chen J, Johannesson $M$, Kind $P, X u$ $\mathrm{L}$, Zhang $\mathrm{Y}$, et al. Population health status in China: EQ-5D results, by age, sex and socioeconomic status, from the National Health Services Survey 2008. Qual Life Res [Internet]. 2011 Apr [cited 2016 Jan 5];20(3):309-20. Available from: http://www.pubmedcentral.nih.gov/ articlerender.fcgi? artid $=3052443 \&$ tool=pmcentre z\&rendertype $=$ abstract

20. QualityMetric. SF Health Surveys [Internet]. 2016 [cited 2016 Jan 5]. Available from: https://www optum.com/optum-outcomes/what-we-do/ health-surveys.html

21. Ministry of Health of Chile. II Encuesta de calidad de vida y salud. Santiago de Chile: Ministry of Health of Chile; 2006. Spanish.
22. Ministry of Health of Chile: Pontificia Universidad Católica de Chile. Encuesta Nacional de Salud 2009 - 2010, V Resultados. Santiago de Chile: Ministry of Health of Chile; 2010. Spanish.

23. Ministry of Health of Chile; Pontificia Universidad Católica de Chile. Encuesta Nacional de Salud 2009-2010, III Metodología. Santiago de Chile: Ministry of Health of Chile; 2010. Spanish.

24. Ware JE. How to Score Version 2 of the SF-12 Health Survey. San Diego: Health Assessment Lab; 2002. 267 p.

25. Ministry of Social Development of Chile. Encuesta de caracterización socio-económica nacional. Santiago de Chile: Ministry of Social Development of Chile; 2009. Spanish.

26. Soares J, Simões E, Ramos LR, Pratt M, Brownson RC. Cross-sectional associations of healthrelated quality of life measures with selected factors: a population-based sample in Recife, Brazil. J Phys Act Health [Internet]. 2010 Jul [cited 2016 Jan 5];7 Suppl 2:S229-41. Available from: http://www.ncbi.nlm.nih.gov/pubmed/20702911

27. Ministry of Social Development of Chile. Encuesta de caracterización socio-económica nacional. Santiago de Chile: Ministry of Social Development of Chile; 2000. Spanish.

28. Ministry of Social Development of Chile Encuesta de caracterización socio-económica nacional. Santiago de Chile: Ministry of Social Development of Chile; 2003. Spanish.

29. Ministry of Health of Chile. Objetivos sanitarios para la década 2000-2010. Evaluación a mitad del período. Evaluación objetivo III: Disminuir las desigualdades en salud. Santiago de Chile: Ministry of Health of Chile; 2006. Spanish.

30. Ministry of Health of Chile; Chilean Institute of Occupational Safety. Primera encuesta nacional de condiciones de empleo, trabajo, salud y calidad de vida. Santiago de Chile: Ministry of Health of Chile; 2010. Spanish.

31. Ministry of Health of Chile. I Encuesta de calidad de vida y salud. Santiago de Chile: Ministry of Health of Chile; 2000. Spanish.

32. Government of Chile. Superintendencia de ISAPRES. Estado de salud de beneficiarios del sistema de salud de Chile: 2004-2005. Santiago de Chile: Government of Chile; 2006. Spanish.

33. Ministry of Social Development of Chile. Encuesta de caracterización socio-económica nacional. Santiago de Chile: Ministry of Social Development of Chile; 2011. Spanish.

34. Hoffmeister L. Normas poblacionales de referencia del Cuestionario de Calidad de Vida Relacionada a la Salud, SF-12 para población adulta chilena: Encuesta de Calidad de Vida y Salud 2006. Santiago de Chile: Ministry of Health of Chile; 2007. Spanish.

35. Conceição P, Bandura R. Measuring subjective wellbeing: A summary review of the literature [Internet]. New York: UNDP; 2008. Available from: https://pdfs.semanticscholar.org/1772/72a22341 1959e11966369c04b6f88a7b07c8.pdf

36. Ministry of Social Development of Chile. Encuesta de caracterización socio-económica nacional. Santiago de Chile: Ministry of Social Development of Chile; 2013. Spanish.

\section{THE AUTHORS}

Isabel Matute Willemsen (Corresponding author: mimatute@udd.cl), sociologist with a master's degree in public health, Universidad del Desarrollo de Chile, Santiago, Chile.

Soledad Burgos De la Vega, veterinarian with a doctorate in public health and environment, Universidad de Chile, Santiago, Chile.

Tania Alfaro Morgado, physician specializing in public health with a master's degree in public health, Universidad de Chile, Santiago, Chile.

Submitted: February 1, 2016

Approved for publication: June 1, 2017

Disclosures: None 